\title{
Foiling the barium swallow!
}

\author{
David McCrory, ${ }^{1}$ Caroline Smith, ${ }^{2}$ Susanne Hampton ${ }^{2}$
}

${ }^{1}$ ENT, Craigavon Area Hospital, Portadown, UK

${ }^{2}$ ENT, Royal Victoria Hospital, Belfast, UK

\section{Correspondence to David McCrory,} dmccrory07@qub.ac.uk

Accepted 28 November 2018

\section{DESCRIPTION}

This fit and well woman in her 40 s presented to $\mathrm{A}+\mathrm{E}$ with a foreign body throat sensation and dysphagia after swallowing her analgesic tablets in the middle of the night. She was reviewed by the ear, nose and throat team and at that stage she was tolerating fluids, had no airway difficulties and could mobilise her neck. Chest and lateral neck $\mathrm{X}$-rays were normal and flexible nasendoscopy revealed no abnormalities of the larynx. A hypopharyngeal/oesophageal abrasion sustained as she swallowed the tablets was the presumed diagnosis and she was discharged with advice to return in 48 hours if no improvement. She was admitted 3 days later with ongoing symptoms and treated with steroids and analgesics for 48 hours until she clinically improved for discharge. An outpatient barium swallow was requested and performed 5 days later. She remained as inpatient for 48 hours after the swallow test for symptom control and for the test results. It was reported as a normal study with 'Buildup of contrast in the oesophagus adjacent to $T 1$ and $T 2$ which likely represents barium accumulating between mucosal folds' (figure 1). She was again discharged but given the persistent symptoms she was referred for outpatient oesophagogastroduodenoscopy (OGD). Five days later, an OGD revealed she had swallowed her tramadol tablets whole in the original foil packet which was lodged in the upper oesophagus (figure 2). She underwent rigid oesophagoscopy and removal of foreign body uneventfully (17 days after ingestion of her tablets!) and she was discharged after a period of observation.

Foreign body in the oesophagus carries a significant risk of morbidity and mortality; due to oesophageal perforation, fistulisation, mediastinitis/sepsis and airway obstruction. ${ }^{1}$ A detailed history of what has been ingested and when is required to help grade the urgency of investigation and removal, as some objects may be sharp or corrosive, and so on, so carry higher risk of perforation and its sequelae. This case teaches us not to rely on barium swallow to rule out

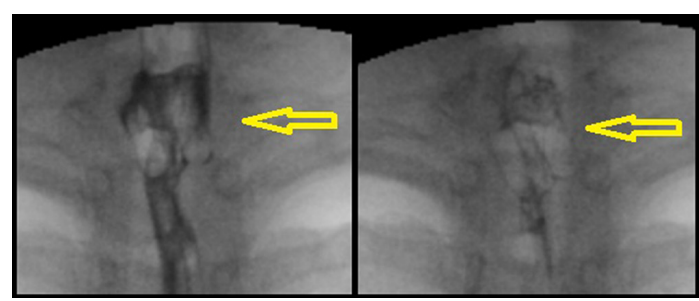

Figure 1 Barium swallow image during and after contrast swallow; reported as buildup of barium between mucosal folds but retrospectively can delineate the packet of tablets ingested.

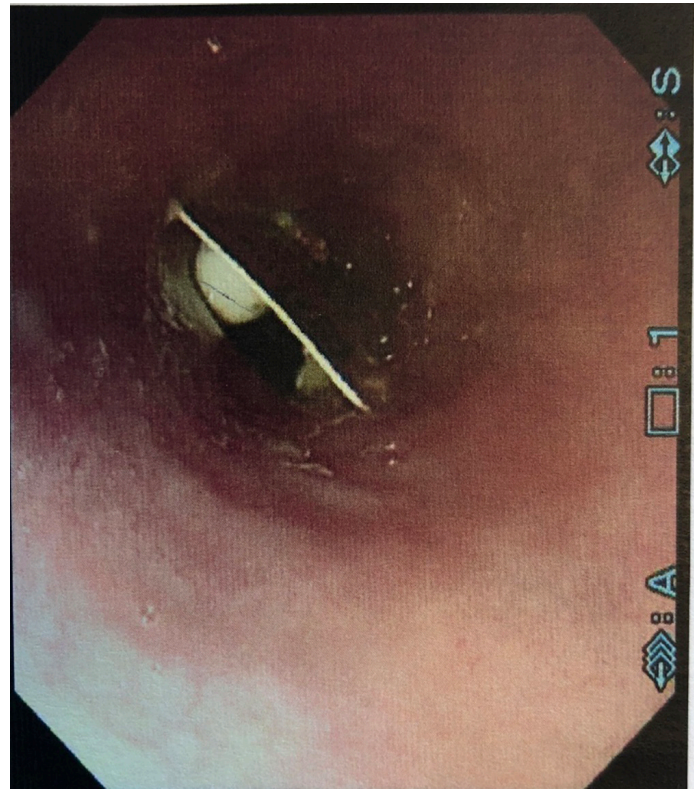

Figure 2 Picture taken from oesophagogastroduodenoscopy (OGD); packet of tramadol tablets lodged in upper oesophagus.

foreign body oesophagus; and the need for more sensitive investigations like CT scan or oesophagoscopy. A study published in peer-reviewed Acta Radiologica found the sensitivity of barium swallows to be $87.5 \%$ for detection of upper oesophageal foreign bodies, with fish bone being the main foreign body not detected. ${ }^{2}$ A larger study published in the Annals of Otology, Rhinology \& Laryngology found that CT scan has $100 \%$ sensitivity for ingested foreign body, and they are also more useful at diagnosing

\section{Patient's perspective}

I had no idea I swallowed this! It was a very frightening 3 weeks and I couldn't believe when I saw the picture! Thank you for all your help.

\section{Learning points}

- Higher sensitivity of CT scan and oesophagoscopy compared with barium swallow for suspected oesophageal food bolus.

- Early oesophagoscopy and removal of impacted food bolus/foreign body to avoid oesophageal perforation and sequelae.

- Caution with patients who cannot provide reliable history as to what was ingested and when. 
complications such as perforation. ${ }^{3}$ CT scan may also be a safer option than OGD, particularly pertinent in elderly patients with multiple comorbidities. Where clinical suspicion of foreign body oesophagus is high oesophagoscopy or CT scan would be preferred ahead of barium swallow, however, in this case a foreign body was thought to be highly unlikely as the patient could relay a full history and the foreign body in question should have been a dissolvable tablet. In retrospect viewing of the barium swallow we can see the tramadol packet, however everyone was surprised when it was discovered at OGD!

Contributor DMC: lead author, reviewed notes and images for case report; literature review. CS: Registrar who performed rigid oesophagoscopy and removal of foreign body; advice on case structure and discussion; review of final submission. SH: supervising consultant whose care the patient was admitted under; advice on case structure and discussion; review of final submission.
Funding The authors have not declared a specific grant for this research from any funding agency in the public, commercial or not-for-profit sectors.

Competing interests None declared.

Patient consent for publication Obtained.

Provenance and peer review Not commissioned; externally peer reviewed.

\section{REFERENCES}

1 Pelucchi S, Bianchini C, Ciorba A, et al. Unusual foreign body in the upper cervical oesophagus: case report. Acta Otorhinolaryngol Ital 2007;27:38-40.

2 Marco De Lucas E, Sádaba P, Lastra García-Barón P, et al. Value of helical computed tomography in the management of upper esophageal foreign bodies. Acta Radiol 2004;45:369-74.

3 Liu YC, Zhou SH, Ling L. Value of helical computed tomography in the early diagnosis of esophageal foreign bodies in adults. Am J Emerg Med 2013;31:1328-32.

Copyright 2018 BMJ Publishing Group. All rights reserved. For permission to reuse any of this content visit

https://www.bmj.com/company/products-services/rights-and-licensing/permissions/

BMJ Case Report Fellows may re-use this article for personal use and teaching without any further permission.

Become a Fellow of BMJ Case Reports today and you can:

- Submit as many cases as you like

- Enjoy fast sympathetic peer review and rapid publication of accepted articles

- Access all the published articles

Re-use any of the published material for personal use and teaching without further permission

For information on Institutional Fellowships contact consortiasales@bmjgroup.com

Visit casereports.bmj.com for more articles like this and to become a Fellow 